Agricultural Journal 7 (3): 191-193, 2012

ISSN: $1816-9155$

(C) Medwell Journals, 2012

\title{
Effect of Seed Pre-Treatment and Sowing Orientation on Germination of Balanites aegyptiaca (L.) Del. Seeds
}

\author{
A.A. Elfeel \\ Department of Arid Land Agriculture, Faculty of Meteorology, \\ Environment and Arid Land Agriculture, King Abdulaziz University, Jeddah, Saudi Arabia
}

\begin{abstract}
Seeds of Balanites aegyptiaca stored for 1 year were germinated using cold and boiling water pre-treatments and different sowing orientations. Whole fruits were soaked in cold water for $(18,24$ and $48 \mathrm{~h}$, respectively) while extracted sun dried seeds were immersed in boiling water for $7 \mathrm{~min}$. Seeds of each treatment were sown in three orientations (seeds laid vertically with stalk end downwards, seeds laid horizontally and seeds laid vertically with stalk end upwards). The study recommend germinating Balanites seeds after extraction of seed by soaking of fruits for $18 \mathrm{~h}$ and sowing without germination pre-treatment in horizontal orientation.
\end{abstract}

Key words: Pre-treatment, sowing orientation, cumulative germination, soaking, boiling, Saudi Arabia

\section{INTRODUCTION}

Balanites aeyptiaca (L.) Del. known as Heglieg tree is a multi-branched medium sized spiny evergreen tree. The tree is famous as multi-products tree species that thrives in dry areas of Africa, Arab Peninsula and as far as Pakistan (Arbonnier, 2004). Natural regeneration is by seeds, root suckers and coppicing (ICRAF, 1998; El-Nour, 1994). Seeds of Balanites are highly variable among sources in weight and morphology (Elfeel and Warrag, 2006) and also in germination (Elfeel et al., 2009). Fresh seeds of $B$. aegyptiaca are said to germinate readily without treatment (Sayda, 2002). However, seeds that pass intestinal tract of animals germinate particularly well (Von Maydell, 1986). Different seeds pre-treatments were tested to enhance germination of Balanites (Hall and Walker, 1991). Soaking seeds in hot water, cold water or boiling are methods that have been reported to improve germination (Schmidt and Joker, 2000; Zarad et al., 1998; ICRAF, 1998; Mbah and Retallick, 1992). However, experiments in Sudan showed that pre-treatment of seeds by boiling water reduced germination over untreated seeds. Also, Schelin et al. (2003) found that treatment of Balanites seeds with different methods of scarification and gibberelic acid was not significantly increased germination over control untreated seeds. Sowing seeds with mesocarp resulted in delayed germination while sowing seeds with stalk end downwards or upwards reduced germination (El-Nour and Kalislo, 1995). The tree recently received a lot of attention due its high fruit value.
The fruits had a very high content of oil, protein and minerals (Elfeel, 2010). The oil can be used for food (Obidah et al., 2009), medicine (Al Ashaal et al., 2010) and as a source for biodiesel production (Chapagain et al., 2009). The most important product is saponin which is extracted from seed kernel and fruit fleshy pulp in addition to other parts. It has remarkable medicinal value (Beit-Yannai et al., 2011; Farid et al., 2002). This high value of the tree targeted the species as potential multi-purposes tree for afforestation in arid zones (NRC, 2008). Understanding the germination potential of this tree will be very important for domestication and afforestation programs of the species. The aim of this study was to investigate the best germination of Balanites seeds stored for 1 year. Specifically, to investigate the effects of cold and boiling water pre-treatments on germination of Balanites seeds and to determine the best seed sowing orientation.

\section{MATERIALS AND METHODS}

Fruits of Balanites collected from Kassala area Eastern Sudan (Lat. $15.467^{\circ} \mathrm{N}$; long. $36.400^{\circ} \mathrm{E}$; soil silty caly; rainfall $400 \mathrm{~mm}_{\text {annum }}{ }^{-1}$; number of seeds $\mathrm{kg}^{-1} 418$ ) in Feb., 2007. The seeds were then stored at room temperature in normal store for 1 year. Two samples were drawn for seed pre-treatments and germination. In sample one, whole fruits were soaked in water for 18,24 and $48 \mathrm{~h}$. After that the mesocarp and the exocarp were thoroughly cleaned by hand and washed out. In sample two, the fruit

Corresponding Author: Abdalla A. Elfeel, Department of Arid Land Agriculture, Faculty of Meteorology, Environment and Arid Land Agriculture, King Abdulaziz University, P.O. Box 80208, 21589 Jeddah, Saudi Arabia 
were soaked in water for $18 \mathrm{~h}$ and seeds were extracted from the mesocarp and exocarp and sun dried for $48 \mathrm{~h}$. The sun dried seeds were divided into two lots. Lot one was immersed in boiling water for $7 \mathrm{~min}$ and then left to coal slowly. Lot two was control untreated seeds. The seeds were then sown in pot trays under nursery $(50 \%$ shade) in a mixture of sand and clay (50:50 ratio). Three sowing orientations were used; seed laid vertically with stalk end downwards seeds laid horizontally and seeds laid vertically with stalk end upwards. Three replicates were used for each treatment and 50 seeds were sown in each replicate. The total seeds ( 5 treatments $\times 3$ orientations $\times 3$ reps $\times 50$ seeds $=2250$ seeds). The first germination commenced in day 12 then after that germination count was monitored at 1 week interval for 4 weeks. The germination data were statistically analyzed using SAS Statistical Software; SAS Institute Inc. Version 8.0 (SAS, 2000).

\section{RESULTS AND DISCUSSION}

The results showed a very high significant difference in germination between the different pre-treatments $(\mathrm{p} \leq 0.01)$ (Fig. 1). Soaking fruits in cold water for 18 and $24 \mathrm{~h}$ significantly resulted in higher germination than soaking for $48 \mathrm{~h}$. Also, control untreated seeds has significantly higher germination than seeds boiled in water (Fig. 1). The results confirmed the earlier reports in Sudan by El-Nour et al. (1991) were they found that boiling seeds in water resulted in reduced germination although, it is in contrast with many other studies (Schmidt and Joker, 2000; Zarad et al., 1998). My explanation to these contrasting results may be attributed to the sources variation of the seed tested since, this species is very highly variable in its seeds (Elfeel and Warrag, 2006).

This may also calls for investigating seeds pre-germination treatments over a wide range of sources and over longer periods of storage. Seed oriented vertically with stalk end downwards and seeds laid horizontally showed higher germination percent and highly differed from seeds oriented with stalk end upwards. Apart from El-Nour and Kalislo (1995) who reported that orienting seeds vertically with stalk end downwards resulted in lesser germination, all other studies recorded that best germination normally obtained with seeds oriented vertically with stalk end downwards (Sayda, 2002; Hall and Walker, 1991). Since, orienting seeds with stalk end downwards and laying seed horizontally resulted in very close germination percentage and with no significant differences (Fig. 1), it is better to sow seeds horizontally as this is the normal

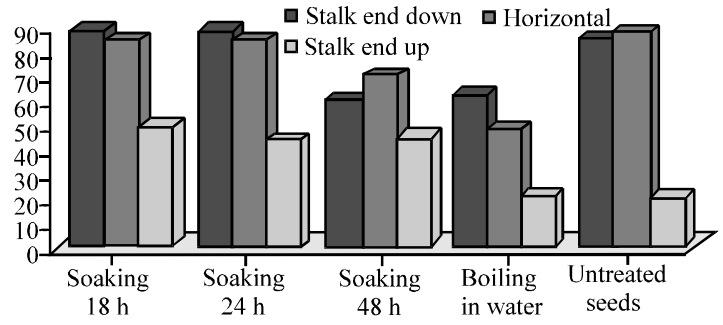

Fig. 1: Cumulative germination percent of B. Aegyptiaca seeds at different pre-treatments and sowing orientations

Table 1: Germination behavior of B. aegyptiaca seeds pre-treated with soaking in cold water and sown at different orientations

\begin{tabular}{llllllllll}
\hline $\begin{array}{l}\text { Sowing } \\
\text { orientation } \\
\text { treatments }\end{array}$ & \multicolumn{3}{l}{$\begin{array}{l}\text { Stalk end } \\
\text { downwards (h) }\end{array}$} & \multicolumn{3}{l}{ Horizontal (h) } & \multicolumn{5}{c}{$\begin{array}{l}\text { Stalk end } \\
\text { upwards (h) }\end{array}$} \\
\hline (weeks) & 18 & 24 & 48 & 18 & 24 & 48 & 18 & 24 & 48 \\
\hline 1 & $0^{\mathrm{a}}$ & $3^{\mathrm{a}}$ & $0^{\mathrm{a}}$ & $2^{\mathrm{a}}$ & $2^{\mathrm{a}}$ & $2^{\mathrm{a}}$ & $0^{\mathrm{b}}$ & $0^{\mathrm{b}}$ & $2^{\mathrm{a}}$ \\
2 & $43^{\mathrm{a}}$ & $40^{\mathrm{a}}$ & $24^{\mathrm{a}}$ & $46^{\mathrm{a}}$ & $37^{\mathrm{a}}$ & $24^{\mathrm{a}}$ & $4^{\mathrm{a}}$ & $5^{\mathrm{a}}$ & $7^{\mathrm{a}}$ \\
3 & $88^{\mathrm{a}}$ & $86^{\mathrm{a}}$ & $55^{\mathrm{b}}$ & $82^{\mathrm{a}}$ & $83^{\mathrm{a}}$ & $64^{\mathrm{b}}$ & $24^{\mathrm{a}}$ & $29^{\mathrm{a}}$ & $24^{\mathrm{a}}$ \\
4 & $88.7^{\mathrm{a}}$ & $88.7^{\mathrm{a}}$ & $60.7^{\mathrm{b}}$ & $84.7^{\mathrm{a}}$ & $86.7^{\mathrm{a}}$ & $69.3^{\mathrm{b}}$ & $48.7^{\mathrm{a}}$ & $44.7^{\mathrm{a}}$ & $44.0^{\mathrm{a}}$ \\
\hline
\end{tabular}

Table 2: Germination behavior of B. aegyptioca seeds pre-treated with boiling water and sown at different orientations

\begin{tabular}{|c|c|c|c|c|c|c|}
\hline \multirow{2}{*}{$\begin{array}{l}\text { Sowing } \\
\text { orientation } \\
\text { treatments } \\
\text { (weeks) }\end{array}$} & \multicolumn{2}{|c|}{$\begin{array}{l}\text { Stalk end } \\
\text { downwards }\end{array}$} & \multicolumn{2}{|l|}{ Horizontal } & \multicolumn{2}{|c|}{ Stalk end upwards } \\
\hline & $\begin{array}{l}\text { Boiling } \\
\text { water }\end{array}$ & Control & $\begin{array}{l}\text { Boiling } \\
\text { water }\end{array}$ & Control & $\begin{array}{c}\text { Boiling } \\
\text { water }\end{array}$ & Control \\
\hline 1 & $5^{a}$ & $9^{a}$ & $3^{\mathrm{a}}$ & $14^{\mathrm{a}}$ & $0^{\mathrm{a}}$ & $1^{\mathrm{a}}$ \\
\hline 2 & $40^{\mathrm{a}}$ & $46^{\mathrm{a}}$ & $26^{b}$ & $59^{\mathrm{a}}$ & $2^{\mathrm{a}}$ & $5^{\mathrm{a}}$ \\
\hline 3 & $57^{\mathrm{b}}$ & $77^{\mathrm{a}}$ & $45^{b}$ & $83^{\mathrm{a}}$ & $16^{b}$ & $18^{\mathrm{a}}$ \\
\hline 4 & $62^{\mathrm{b}}$ & $85^{\mathrm{a}}$ & $48^{b}$ & $86^{\mathrm{a}}$ & $21^{\mathrm{a}}$ & $20^{\mathrm{a}}$ \\
\hline
\end{tabular}

orientation of the seeds when fall in the ground. Also, orienting seeds with stalk end downwards with inexperienced persons can lead to unintentionally sowing the seeds in opposite direction (with stalk end upwards) which will seriously reduce germination percentage. Germination behavior $>4$ weeks showed that soaking for 18 and $24 \mathrm{~h}$ and untreated seeds had higher germination speed than soaking for $48 \mathrm{~h}$ or boiling in water (Table 1 and 2).

\section{CONCLUSION}

The results showed a very high significant difference between treatments and sowing orientations. Soaking for 18 and $24 \mathrm{~h}$ and untreated seeds resulted in higher germination. Also, sowing seeds horizontally or vertically with stalk end downwards had higher germination.

\section{RECOMMENDATIONS}

The study recommends sowing seeds of Balanites at least up to this period of storage without pre-treatment 
and in a horizontal orientation. The seeds also should be extracted after soaking fruits in water for $18 \mathrm{~h}$. However, a range wide study in germination behavior under longer storage conditions may be needed to investigate the effect of geographical sources in germination.

\section{REFERENCES}

Al Ashaal, H.A., A.A. Farghaly, M.M. Abd El Aziz and M.A. Ali, 2010. Phytochemical investigation and medicinal evaluation of fixed oil of Balanites aegyptiaca fruits (Balantiaceae). J. Ethnopharmacol., 127: 495-501.

Arbonnier, M., 2004. Trees, Shrubs and Lianas of West African Dry Zones. 1st Edn., CIRAD, Margraf Publishers GMBH MNHN, USA., ISBN: 2876145790 , Pages: 574.

Beit-Yannai, E., S. Ben-Shabat, N. Gold, B.P. Chapagain, R.H. Liu and Z. Wiesman, 2011. Antiproliferative activity of steroidal saponins from Balanites aegyptiaca: An in vitro study. Phytochem. Lett., 4: 43-47.

Chapagain, B.P., Y. Yehoshua and Z. Wiesman, 2009. Desert date (Balanites aegyptiaca) as an arid lands sustainable bioresource for biodiesel. Bioresour. Technol., 100: 1221-1226.

El-Nour, M. and M. Kalislo, 1995. Effect of pulp and positioning of seeds on germination and juvenile development of heglig (Balanites aegyptiaca (L) De1.). Univ. Khartoum J. Agric. Sci., 3: 87-97.

El-Nour, M., K. El-Khalifa, K. Massimo and B. El-Hassen, 1991. Preliminary study on seed pre-germination treatment and vegetative propagation of Balanites aegyptiaca (L.) Del. Proceedings of the Seminar on Physiology of Arid and Semi-arid Trees, (PASAT'91), Paris, Nancy, France, pp: 413-417.

El-Nour, M.A., 1994. Natural regeneration of Heglig Balanites aegyptiaca (L) Dell on clay soil of central Sudan. Univ. Khartoum J. Agric. Sci., 2: 147-155.

Elfeel, A.A. and E.I. Warrag, 2006. Variation in morphological and chemical characteristics of fruits and seeds among eleven geographical sources of Balanites aegyptiaca (L.) Dell in Sudan. Sudan Silva, 12: $29-40$.

Elfeel, A.A., 2010. Variability in Balanites aegyptiaca var. aegyptiaca seed kernel oil, protein and minerals contents between and within locations. Agric. Biol. J. North Am., 1: 170-174.
Elfeel, A.A., E.L. Warag and H.A. Musnad, 2009. Effect of seed origin and soil type on germination and growth of heglig tree (Balanites aegyptiaca L. (Del) var. aeyptiaca). J. Sci. Technol., 10: 56-65.

Farid, H., E. Haslinger, O. Kunert, C. Wegner and M. Hamburger, 2002. New steroidal glycosides from Balanites aegyptiaca. Helv. Chim. Acta, 85: 1019-1026.

Hall, J.B. and D.H. Walker, 1991. Balanites aegyptiaca: A Monograph. University of Wales, Bangor, UK., ISBN-13: 9780904390759, Pages: 65

ICRAF, 1998. Balanites aegyptiaca. Agroforestree Database, World Agroforestry Centre.

Mbah, J.M. and S.J. Retallick, 1992. Vegetative propagation of Balanites aegyptiaca (L) Del. Commonwealth For. Rev., 71: 52-56.

NRC, 2008. Lost Crops of Africa: Fruits. Vol. 3, National Academies Press, Washington, D.C., USA., ISBN-13: 9780309105965, Pages: 354.

Obidah, W., M.S. Nadro, G.O. Tiyafo and A.U. Wurochekke, 2009. Toxicity of crude Balanites aegyptiaca seed oil in rats. J. Am. Sci., 5: 13-16.

SAS, 2000. SAS Statistical Analysis. Version 8, SAS Institute Inc., Cary, USA..

Sayda, M., 2002. Studies on the physiological, environmental and biochemical factors affecting the germinability of some forest tree species seeds. Ph.D. Thesis, University of Khartoum, Khartoum, Sudan.

Schelin, M., M. Tigabu, I. Eriksson, L. Sawadogo and P.C. Oden, 2003. Effects of scarification, gibberellic acid and dry heat treatments on the germination of Balanites aegyptiaca seeds from the Sudanian savanna in Burkina Faso. Seed Sci. Technol., 31: 605-617.

Schmidt, L.H. and D. Joker, 2000. Balanites aegyptiaca (L.) Dell. Danida Forest Seed Centre Seed Leaflet No. 21, DFSC, Denmark.

Von Maydell, H.J., 1986. Trees and Shrubs of the Saheltheir Characteristics and Uses. GTZ, Eschborn, Germany.

Zarad, S.S., Y.A. Hossny and H.M. El-Bagoury, 1998. Effect of various treatments on seed germination and water application on vegetative growth of desert date (Balanites aegyptiaca Linn) Seedlings grown in different soils. Egypt. J. Physiol. Sci., 21: 147-159. 